\title{
Geomechanical Hazards related to River Hydraulics and Remedial Measures: Selected Case Studies in India
}

\author{
JOYDEEP DUTTA $^{1} \quad$ SUDIP BASACK $^{2 *}$ GHRITARTHA GOSWAMI $^{3} \quad$ BINI KIRON $^{3}$ \\ ${ }^{1}$ Silchar Water Resources Circle, Silchar, Assam, INDIA \\ ${ }^{2}$ Elitte College of Engineering, Affiliation: MAKA University of Technology, \\ Kolkata 700113, INDIA \\ ${ }^{3}$ North Eastern Regional Institute of Science and Technology, \\ Nirjuli, Arunachal Pradesh, INDIA
}

\begin{abstract}
River science and engineering has been one of the important study areas for geologists, hydrologists and engineers. The open channel flow and associated hydraulics often initiate several geomechanical hazards including silting and scouring, meandering and migration, floods, etc. Such hazards may lead to disastrous consequences if adequate remedial measures are not undertaken by proper river training works. This paper presents selected case studies in northern and north-eastern parts of India where such hazards occurred due to migration of river channel and flooding of adjacent lands. The two study areas have been the Kosi and the Brahmaputra river basins. In the former study area, hazards took place due to eastward migration, whereas in the latter case, significant damages occurred due to scouring and erosion. The descriptions of the hazards occurred, and the mitigation techniques adopted have been briefly summarized in this paper. A critical analysis with prediction techniques for flood occurrence probability and erosion potential has been conducted as well. The relevant conclusions are drawn therefrom.
\end{abstract}

Key-Words: - Flood, Marginal embankment, River hydraulics, River migration, Spur

Received: April 12, 2021. Revised: October 15, 2021. Accepted: November 5, 2021. Published: December 2, 2021.

\section{Introduction}

Rivers typically originates from mountains, flow through the mountainous areas, thereafter alluvial plains and finally joins the sea. The initial stage of river in the upper reaches includes rocky and boulder stages, where the flow velocity is significantly high due to steep altitude. Later, the river flowing through the alluvial plain follows a meandering pattern, initiating silting and scouring to the flow channel. Prior to joining the sea, the flow velocity is significantly reduced with wider channel cross section, where the river is affected by tidal fluctuations of the sea. This final portion of the river is termed as tidal river [1].

Rivers in flood plain may be classified as aggrading, degrading, stable and deltaic. When the rived bed slope is below its critical value, velocity is below threshold, which initiates silting of its bed load. Such a river is termed as aggrading river. An opposite phenomenon occurs in case of a degrading river. A neither siltation, nor scour state is sustained in case of a stable river, when the bed slope is in the verge of its critical value. Before joining sea, when the river is divided into several branches forming a delta shape, the particular portion of river is termed as deltaic [2].

Meandering of a river is defined as the deviation of its flow path form its axial direction to form successive bends of reverse curvature. The meandered river takes the shape of the alphabet ' $S$ '. When an alluvial river carries significantly high amount of silt charge with the flowing water, the river behaves to be aggrading, thus remarkable siltation takes place. If such siltation occurs near a particular side of the river channel, the channel area is reduced, initiating rise in the river velocity. Thus, the opposite bank is attacked by the increased flow velocity, producing scouring. This continuous process introduces several bends of reverse curvature, and accordingly, the meandering of river takes place [3]. This hydrogeological process is illustrated in Fig.1(a). A schematic sketch showing important geometric parameters of a meandering river is portrayed in Fig. 1(b).

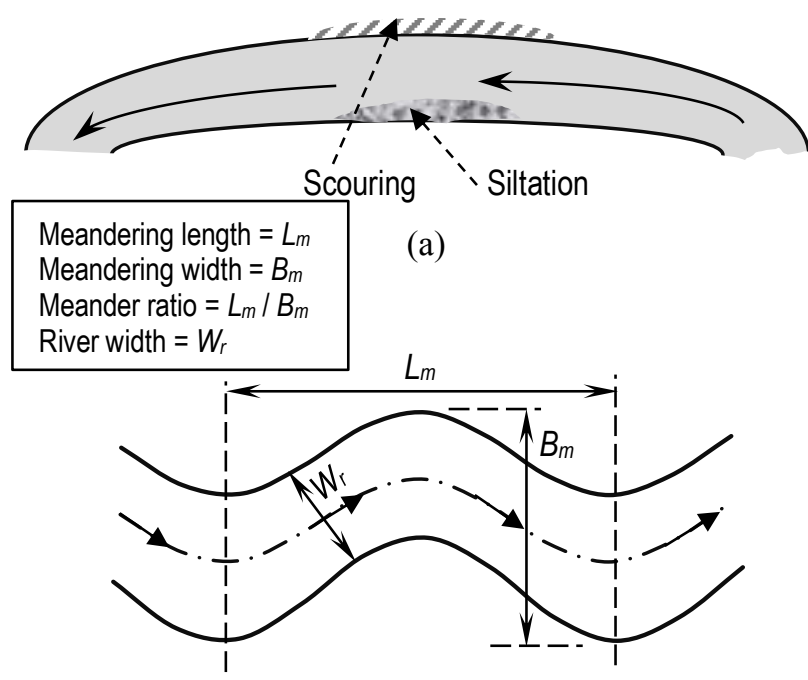

(b)

Fig 1. (a) Siltation and scouring, and (b) meander parameters

The complex channel pattern and erratic shifting nature of the river channels have important implications for flood control by embankments. Unprotected embankments cannot be expected to remain immune to river erosion for many years, even if they are initially 
setback some distance from the banks. Also, at many locations, flood flows strike the banks or embankments at severe angles of attack, producing deep scour in the river-bed and undermining the banks. Prediction of future river behavior is admittedly difficult, but it can be added by study of the satellite imagery. Erosion protection is currently being practiced using spurs or groins mostly constructed at right angles to the embankments, to derive the best results. [4].

\section{Study Areas}

The study areas are located in northern and northeastern parts of India. Two distinct study areas, namely the flood plain of the rivers Kosi and the Brahmaputra in India, were considered to carry out the case studies, as shown in Fig.2.

Both the study areas exhibited similar nature of geomechnical hazards of river migration initiating significant scour and erosion. Also, in both the study areas, remedial measures adopted were in multilevels and multi-phases, which revealed as effective techniques in mitigation of hazards. The first author was actively involved in field-based investigations at both the study areas in official capacity during professional training at Water Resources Department, Indian Institute of Technology, Roorkee, India. Hence, these two specific study areas were chosen.

The river Kosi, also known as 'Saptakoshi' (means seven upper tributaries), is the third largest Himalayan river originating from the central Himalayas in Nepal at an altitude of about $8 \mathrm{~km}$ above the mean sea level. After crossing the mountainous terrains for about a stretch of $42 \mathrm{~km}$ in Nepal, the river enters the alluvial plain in India at a village named as Bhimnagar in the state of Bihar and ultimately joins Ganga near Kursela. The river flows for about $260 \mathrm{~km}$ from Bhimnagar till meeting the river Ganges. The alluvial fan of the river Kosi is one of the world's largest, with the lateral shifting over $120 \mathrm{~km}$. The basin is surrounded by ridges, and the river is attributed to heavy silt charge during the monsoon season [5].

The Brahmaputra basin is situated in northeastern part of India and extends up to Bangladesh. The river basin extends a large area covering Arunachal Pradesh and Assam in India and northern parts of Bangladesh. In India, it is bounded by the great Himalayan range on the North, the Patkai and the Naga hill ranges on the east and the Khasi hills on the south. The western part of the basin is the North Bengal. Brahmaputra is one of the biggest rivers in the world and ranks fifth in respect of average annual discharge, annual sediment load, catchment area and for its length. The specific yield of the river has been 0.22 cumec $/ \mathrm{km}^{2}$ which is the highest in the world [6].

The two specific case studies related to the above study areas producing geomechanical hazards and remedies taken are described in the following sections.

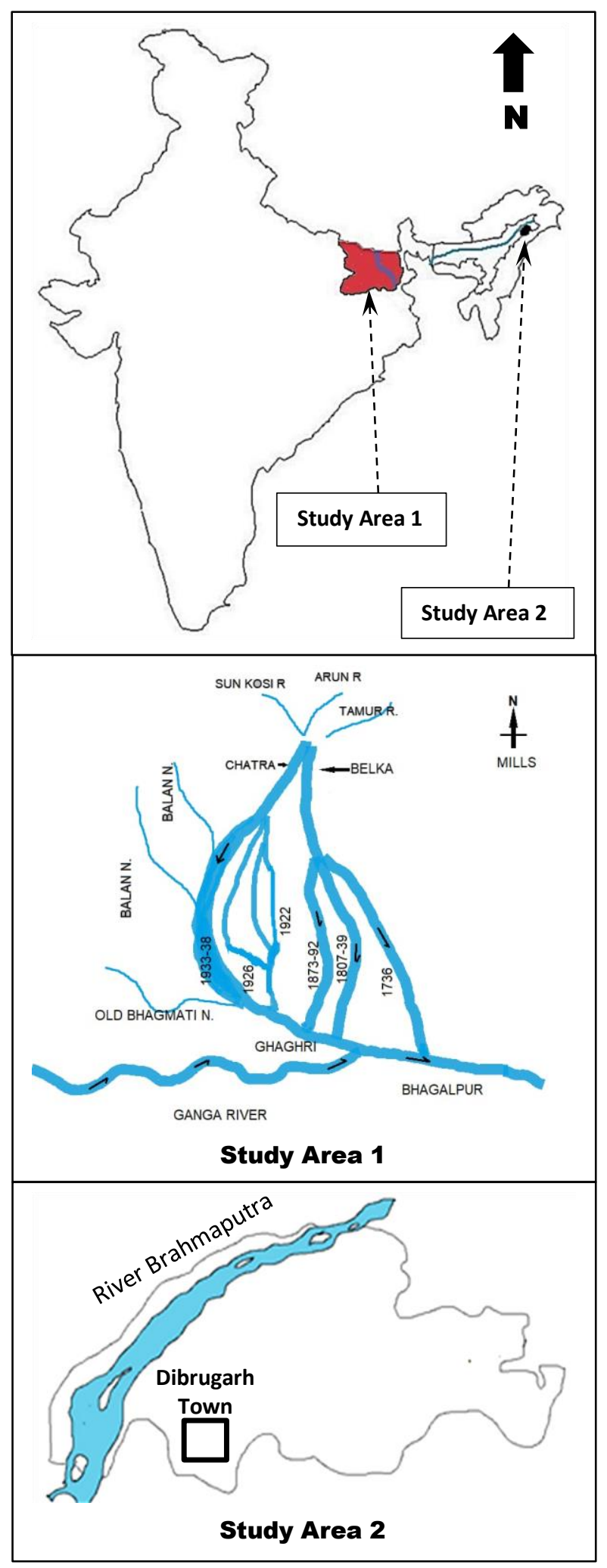

Fig 2. The study areas

\section{Case Study 1: Kosi River}

The state of Bihar in India is surrounded by Nepal in the north, while the states of Jharkhand, West Bengal and Utter Pradesh in the south, east and west, respectively. Bihar is a flood prone state with nearly $50 \%$ annual loss due to flood. Every year, the river Kosi in Bihar with their number of tributaries, initiate flood devastation in the monsoon period by inundation and erosion.

The recurring annual disaster of the state of Bihar in India is particularly associated with flood of the Kosi 
River in the northern part. On account of the resulting huge damages and suffering of the people, the river is named as the 'river of sorrow', like the yellow river of China.

\subsection{Hydrological and Geomechanical Hazards}

As per the historical evidence, the river Kosi has been observed to shift up to about $110 \mathrm{~km}$ from east to west during the last 150 years, i.e., since the commencement of $18^{\text {th }}$ century. In this process of migration, siltation took place in an area of about $13,000 \mathrm{~km}^{2}$ in India and about $1000 \mathrm{~km}^{2}$ in Nepal. The gradient of the river is found to be about $1 \mathrm{~V}: 5 \mathrm{H}$ in the upstream of Chhatri, which is quite steep. In the dry seasons, the river channels are likely to be refilled subsequently. Borehole data near Belka hill region in the study area indicated about $900 \mathrm{~mm}$ thick medium sand layer followed in sequence $125 \mathrm{~mm}$ of coarse sand and boulders, $150 \mathrm{~mm}$ of medium sand and $1475 \mathrm{~mm}$ of gravels and boulders. As the river enters the plain terrain, the coarsest material is dropped first and then the smaller ones. The gradual westward shift of the river occurred by sticking to its original channel at the Belka hills. The observed average migration rate of the river is given in Table 1 and Fig 3 [7].

In the $42 \mathrm{~km}$ reach from Chhatri to Bhimnagar where a barrage was constructed during 1959-1963, the average flood gradient is $8.73 \times 10^{-4}$ downstream of the barrage, which gradually flattened to $0.61 \times 10^{-}$ ${ }^{4}$ to about $130 \mathrm{~km}$ downstream.

The westward migration of the river is possibly due to the existing transverse slope in the terrain of the study area. Since the direction of open channel flow occurred at right angles to the contours, the tendency of scour and erosion increased significantly, which enlarged the channel initiating river migration. Similar observation is found in the case of erosion gullies, which cross the contours at right angles [8]. Another major cause of migration has been identified as excessive sediment load (about 0.43 million ton $/$ year $/ \mathrm{km}^{2}$ ) during flood, which in turn attributed to a large variation in stream discharge, slope, and geologically young rock formation [9].

\subsection{Remedial Measures}

To provide appropriate remedial measures in the study area against the geomechanical hazards described above, extensive construction of marginal embankments was taken up from the year of 1955 onwards. On the eastern side, the embankment was built for $101 \mathrm{~km}$ downstream of Bhimnagar, while on the western side, the construction length was $118 \mathrm{~km}$. The spacing between the embankments varied from 5 to $16 \mathrm{~km}$. The sluice-type barrage of about $2 \mathrm{~km}$ length and $54.25 \mathrm{~m}$ width with multiple gates was constructed with facility of pedestrian and vehicular passages. Afflux bunds were constructed to a length of about $40 \mathrm{~km}$ on the east and $14 \mathrm{~km}$ on the west of the barrage [10]. The position of barrage is shown in the sketch in Fig 4. As observed, a sluice-type barrage is an effective river training work [11].
Table 1. Average rates of migration of Kosi river

\begin{tabular}{|c|c|c|c|}
\hline Year & $\begin{array}{c}\text { Period of } \\
\text { Movement }\end{array}$ & $\begin{array}{c}\text { Approximate } \\
\text { distance moved } \\
(\mathrm{km})\end{array}$ & $\begin{array}{c}\text { Rate } \\
(\mathrm{km} / \\
\text { year})\end{array}$ \\
\hline $1736-1770$ & 34 & 10.7803 & 0.3171 \\
\hline $1770-1823$ & 53 & 9.3322 & 0.1761 \\
\hline $1823-1856$ & 33 & 6.1142 & 0.1853 \\
\hline $1856-1883$ & 27 & 12.872 & 0.4767 \\
\hline $1883-1907$ & 24 & 18.5035 & 0.7710 \\
\hline $1907-1922$ & 15 & 10.9412 & 0.7294 \\
\hline $1922-1933$ & 11 & 28.962 & 2.6329 \\
\hline $1933-1950$ & 17 & 17.699 & 1.0411 \\
\hline
\end{tabular}

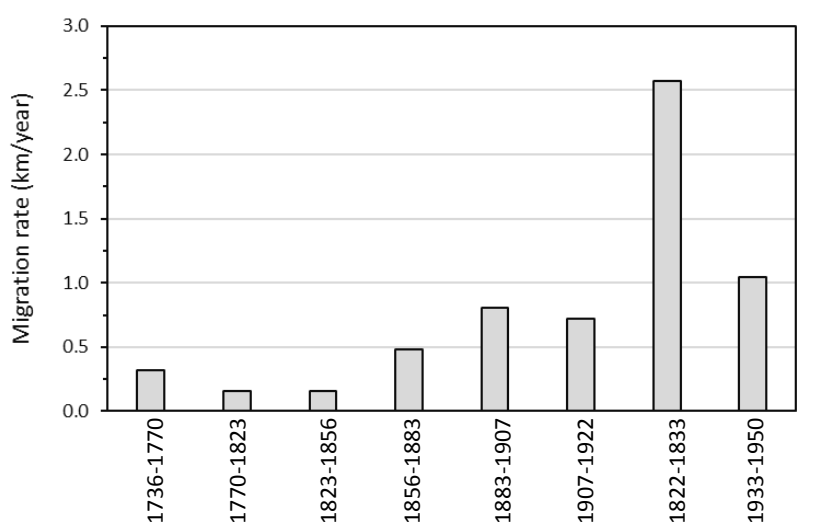

(a)

\begin{tabular}{|c|c|}
\hline $\begin{array}{c}\text { Depth below } \\
\text { river bed level } \\
(\mathrm{m})\end{array}$ & Observed soil type \\
\hline $0-0.9$ & Medium sand \\
\hline $0.9-1.025$ & $\begin{array}{c}\text { Coarse sand with } \\
\text { boulders }\end{array}$ \\
\hline $1.025-1.175$ & Medium sand \\
\hline $1.175-2.650$ & Gravels and boulders \\
\hline
\end{tabular}

(b)

Fig 3. (a) Year-wise river migration rate, and

(b) Bore hole data

Appropriate protective spurs were provided both upstream and downstream of the barrage. Initially, the river tended to attack on the western bank, but later the main current shifted to the eastern bank. The embankment was quite effective for flood protection, although minor drainage congestion problems crept in.

Prior to construction of barrage, the reach of about $102 \mathrm{~km}$ downstream of Chhatra was degrading and that further downstream was aggrading. Post-construction observation indicated that the $42 \mathrm{~km}$ reach downstream of 


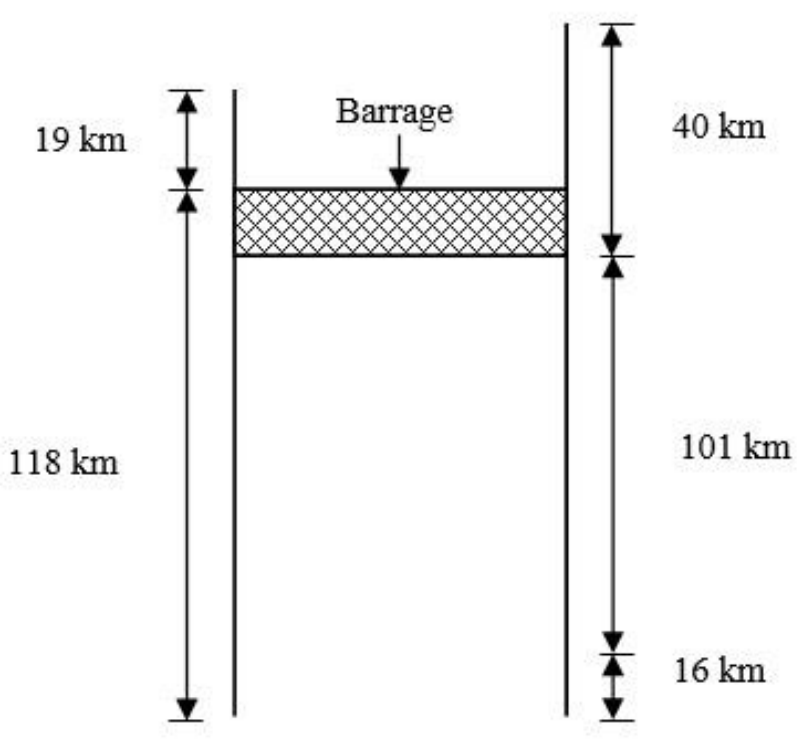

Western Side

Eastern Side

Fig 4. Sketch showing position of Kosi river barrage

Chhatra become aggrading, which continued up to about $16 \mathrm{~km}$ downstream of the barrage, while for further downstream of about $100 \mathrm{~km}$, the aggradation continued [12]. This is portrayed in Fig 5.

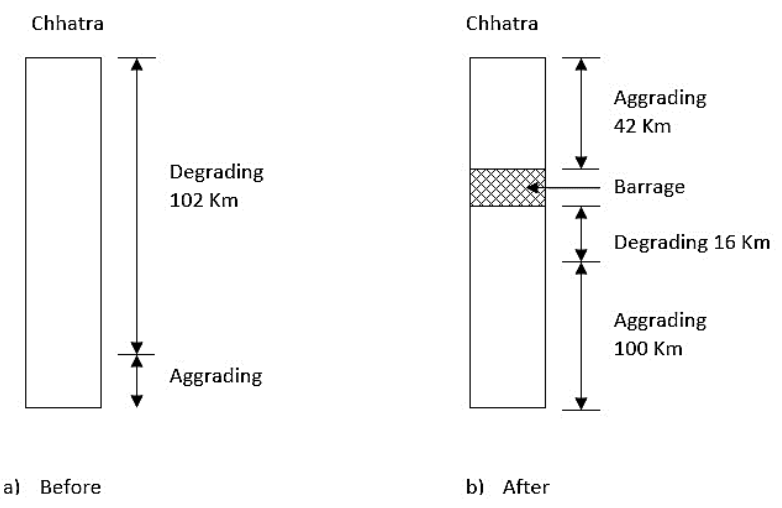

Fig 5. Comparison of sediment load scenarios

Despite the above measures, the problem of huge sediment load and aggradation of river cross section was yet to find a solution. The annual sediment load of the river was estimated as $95 \mathrm{Mm}^{3}$. This was reduced to about $15.6 \mathrm{Mm}^{3}$; possibly, the balance load was deposited on the flood plains. Measurements after banking indicated an average deposit rate of $84 \mathrm{Mm}^{3} /$ year [13].

More details of the remedial measures undertaken has been sequentially described below:

a) Levels of Flood Protection: The appropriate levels of flood protection was based on the expected frequency or probability of overtopping for different categories of land or property requiring protection, for example: agricultural land, villages, towns and cities. The population was made aware of the limitations of flood protection and of planned emergency measures to provide warning and protect life during disaster.

b) Hydraulic Consequences of the Embankment: Using historical river discharge and water level data, efforts were made to investigate the rise in flood level with overbank spilling of the existing embankments and confining flood flows withinin the boundaries of river itself. Attention was given to the consequences of further extending the embankment system.

c) Landslide Dams on Tributaries: On some northside tributaries of the river Kosi, the hazards to life resulting from the formation and breaching of temporary dams composed of landslide detritus were very high. The full geographical extent of the problem were studied for the development of systems for warning, evacuation and contolled breaching.

d) Erosion Control: The erosive potential of the Kosi is extremely high and has led to frequent pulling back or retiring of flood control embankments, with adverse social consequences.

e) Floodplain Agriculture: The National Commission of Agriculture (1976) recommended that one way to minimize the damage from flooding is to change the cropping pattern such that the flood season was avoided.

f) Fisheries: Fish is the important source of protein in the diet and they also contribute to groundwater recharge. Simultaneously, their potential to mitigate relatively smaller floods is evident.

g) Public Participation and Disaster Relief: Adequate public services were provided by giving shelter and livelihood for the numbers of people who are displaced by flooding, erosion, and retiring of embankments. Also, greater public information, education, and participation in flood and erosion control issues were arranged.

\section{Case Study 2: Dibrugarh Town}

The second study area in this paper has been the Dibrugarh town in the state of Assam in north-eastern part of India. The town in located in the basin of the river Brahmaputra (see Fig 2). The river originates from a glacier at an altitude of $5.3 \mathrm{~km}$ and $63 \mathrm{~km}$ south-east of the Manas Sarawar lake in the south-west of Tibet in China. The total length of the river from its origin in Tibet to its outfall in Bay of Bengal is $2,880 \mathrm{~km}$. After covering a length of $1,700 \mathrm{~km}$ in Tibet, the river enters India in the state of Arunachal Pradesh and thereafter Assam near the village Pasighat, a little upstream of which two other tributaries viz., 'Debang' and 'Lohit' have their confluence with the main basin. From this confluence point downwards, the river is called 'Brahmaputra' whereas in the upper reach falling within the state of Arunachal Pradesh is called 'Debang'. During its course, the river crosses the major cities and town including Dibrugarh, Jorhat, Tezpur, Guwahati, Dhubri, etc. and thereafter enters Bangladesh. In the state of Assam, the river covers about $720 \mathrm{~km}$ through alluvium plains. After crossing the India-Bangladesh border, the river Brahmaputra meets the river Ganges at the village Goalanda which is $20 \mathrm{~km}$ west of Dhubri. It has been observed that Brahmaputra swings at nearly $90^{\circ}$ towards south while traversing through Bangladesh. The united Ganges and Brahmaputra flows in the name of 'Padma' and later it is united with another stream 'Meghna' to falls in the Bay of Bengal [14]. A sketch showing the pathway of the river is portrayed in Fig 5. 
WSEAS TRANSACTIONS ON FLUID MECHANICS DOI: 10.37394/232013.2021.16.20

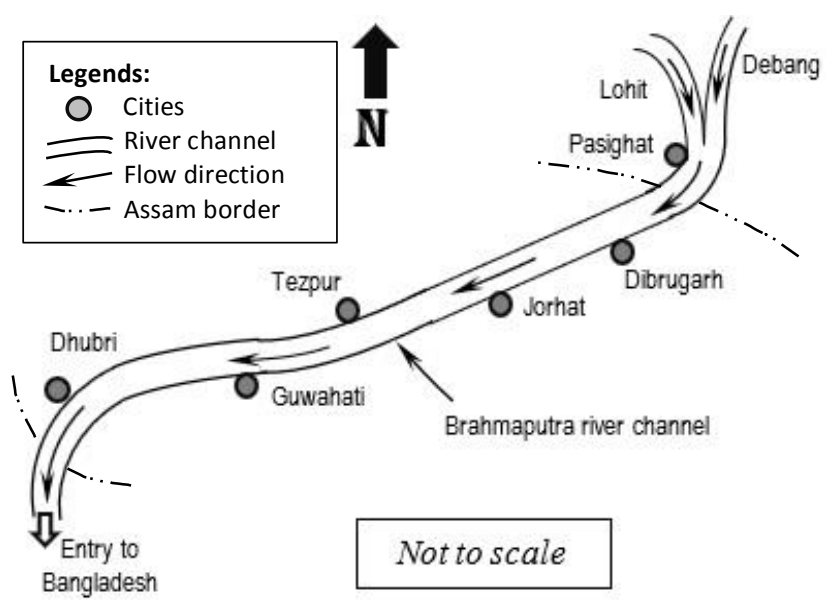

Fig 6. Sketch showing the path of the river Brahmaputra

\subsection{Hydrological Hazards}

The Brahmaputra river consists of a catchment area of $240 \mathrm{k} \mathrm{km}^{2}$ in India. The average monsoon discharge is about $40 \times 10^{3} \mathrm{~m}^{3} / \mathrm{s}$. Due to significantly high discharge and sediment load the river often shifts in course of time. The slope of the river is very steep till it enters India, where a drop of $4.8 \mathrm{~km}$ is achieved in a length of about $2,000 \mathrm{~km}$, the average gradient being reduced from $2.4 \times 10^{-3}$ at Arunachal Pradesh to $0.1 \times$ $10^{-3}$ in the Assam valley. Such abrupt change in the slope initiates the river to be braided [15].

Initially the Dibrugarh Town was located on the bank of the river Dibru, which met Brahmaputra at the village of Mohonagha, while the river Brahmaputra was flowing few kilometers away from the Dibrugarh town. Since the year of 1913, the river Brahmaputra had a gradual trend towards the south bank by the process of scouring, and finally the river Dibru merged with Brahmaputra. Thereafter, the Dibrugarh town is placed on the south bank of Brahmaputra [6, 14].

The Dibrugarh town including adjoining areas are highly erosion prone zone, particularly after the 1930 earthquake. After this earthquake, the southern channel of the river became violently active due to its enormous load of debris from nearby landslides and started attacking the south bank near Dibrugarh town. The dominant flow direction was attacking the bank at an angle $60^{\circ}$, creating enormous bank erosion. This produced significant hydrogeological hazard to the Dibrugarh town, damaging buildings and other civil infrastructures, tea gardens and open lands $[6,14,15]$. To mitigate such disaster, the Government of Assam and the Government of India undertook several remedial measures since the year of 1953, as described below.

\subsection{Remedial Measures}

In the year of 1953, the Government constructed stone revetment of a length of about $460 \mathrm{~m}(1500 \mathrm{ft}$ to be exact) in the worst affected banks of Dibrugarh which is near the old circuit house. However, they were washed away in the floods took place in the year of 1954 whereby remarkably high erosion occurred. With further decision of the Government, planning
Joydeep Dutta, Sudip Basack,

Ghritartha Goswami, Bini Kiron

and design of appropriate protection works were entrusted to the Central Water Commission and the Central Water and Power Research Station, who subsequently undertook model experiments with field-based studies to investigate efficiency of the proposed designs [16]. The remedial measures taken up right after the 1954 flood has been briefly summarized below in sequence.

\section{Protection Works: 1954}

The following constructions were executed:

(1) 5 stone spurs, the first one being of $122 \mathrm{~m}$ in length and the rest were of $61 \mathrm{~m}$.

(2) 15 timber pile spurs, each $61 \mathrm{~m}$ long.

(3) Brush wood protection of the bank between the spurs.

The slope of the stone spurs was designed as $1 \mathrm{~V}: 1.25 \mathrm{H}$ which was later altered on site to $1 V: 1.4 H$ to $1 V: 1.5 H$ for better stability. Around the spurs, $3 \mathrm{~m}$ deep apron and $1 \mathrm{~m}$ thick stone filled cages were also provided. Upstream and downstream revetment with protective aprons were also provided on the banks adjacent to the spurs. The lengths of upstream and downstream revetments for the first spur were $91 \mathrm{~m}$ and $61 \mathrm{~m}$, while for the other spurs, the relevant lengths were 55-61 m and $36.6 \mathrm{~m}$, respectively.

Timber pile spurs consisting of 4 lines of timber piles, each being $61 \mathrm{~m}$ long, 15 numbers and normal to the bank were initially designed. Subsequently, based on in-situ conditions, their length was shortened to $30 \mathrm{~m}-45 \mathrm{~m}$, while the number were increased to 21 .

\section{Protection Works: 1955-1961}

At this phase, few minor additional construction works were executed. No significant damage took place after such works till the year of 1961. The works implemented are enumerated below:

(1) An additional stone spur of $42.7 \mathrm{~m}$ on the upstream of the first stone spur.

(2) An additional stone spur of $610 \mathrm{~m}$ length at the downstream of the $5^{\text {th }}$ stone spur for the purpose of flow diversion.

(3) Few additional timber spurs to strengthen the already constructed old timber spurs. Also, butt heads at pile spurs were provided to strengthen them. This consisted of double rows of T-shaped piles.

(4) A $10 \mathrm{~km}$ long Earthen dyke was also constructed along the riverbank in the town area. to protect the town from flooding.

\section{Protection Works: 1963-1964}

The works at this stage consisted of two distinct phases, as described below:

\section{(a) Phase I:}

The following constructions were taken up during the period of 1963-1964:

(1) 2 semi permeable spurs, each $45.8 \mathrm{~m}$ long.

(2) 6 permeable timber spurs.

(3) Additional revetment along the bank, with the stretches of $55 \mathrm{~m}$ and $36.6 \mathrm{~m}$ in the upstream and downstream, respectively. 
(b) Phase II:

After completion of phase I, heavy erosion took place further downstream and following additional constructions were executed:

(1) 1 semi-permeable spur.

(2) 7 permeable timber spurs.

(3) 1 subsidiary dyke on the downstream.

\section{Secondary Works: 1965-1966}

They included the following:

(1) Few more impermeable stone spurs, $15 \mathrm{~m}$ long.

(2) Strengthening of pile spurs by boulder apron.

(3) Construction of revetment between the spurs.

\section{Major Protection Works: 1967-1979}

In the 1967-1969 attack, the river Brahmaputra eroded a vast area including Mathola tea garden, which was a threat to the Dibrugarh town. Considering the gravity of situation, the Dibrugarh town protection work was extended upwards and this major construction was prolonged two five distinct phases, as described below:

\section{(a) Phase-I (1970):}

In this phase, 3 timber spurs and 29 stone spurs were constructed at the critically affected banks.

\section{(b) Phase II (1973):}

After Government recommendations, three bank heads were constructed to ensure the arrest of erosion. However, they experienced heavy hydraulic pressure and the erosion continued.

\section{(c) Phase III (1975):}

In this phase, strengthening of river bends was initiated. Accordingly, eight permeable spurs with stone apron were constructed. However, the flood occurred in the year of 1977 created severe damage to these measures. The resulting scour eroded about $300 \mathrm{~m}$ deep chunk of lands in the area, developing huge embayment.

\section{(d) Phase IV (1977-1978):}

As the post-flood protective measure, ten timber dampeners with boulder apron was constructed. Unfortunately, almost all of them failed in next flood season.

\section{(e) Phase V (1978-1979):}

After further Government recommendation, land spur was constructed with the following specifications: length $=299 \mathrm{~m}$, crest level $=1.5 \mathrm{~m}$ above HFL, apron width $=3.5 \mathrm{~m}$, apron thickness $=1 \mathrm{~m}$ and side slope $=1 \mathrm{~V}: 1.5 \mathrm{H}$. This land spur is now standing as the key structure of the entire Dibrugarh Town protection work.

The entire remedial measures undertaken in the study area-2 has been depicted in Fig 7.

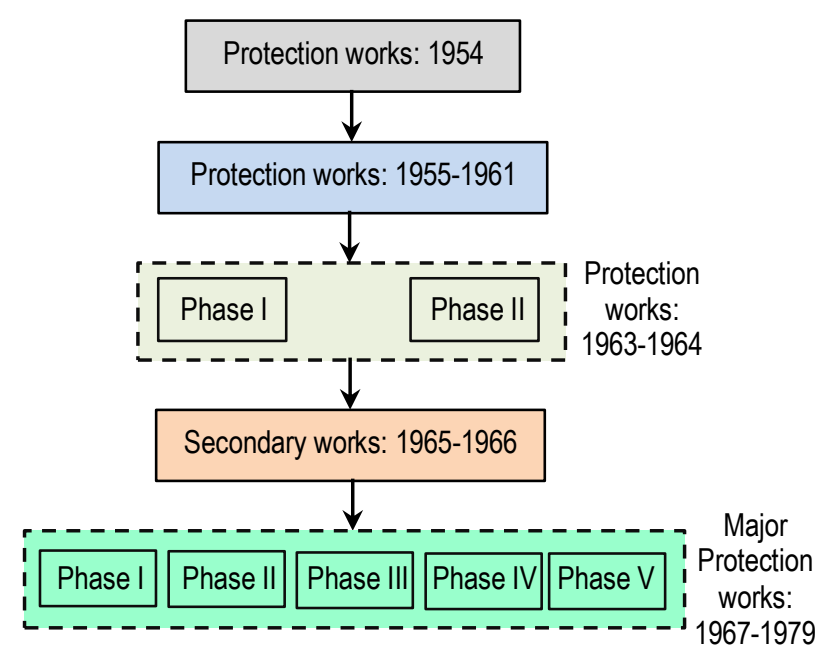

Fig 7. Phase-wise remedial measures in study area - 2

\section{Critical Analysis}

In the above two case studies, it has been observed that the geomechanical and hydrological hazards were slightly different, with the common occurrence of river migration and associated scouring and erosions. Accordingly, the remedial measures undertaken were different. In the first study, the hydraulic structures constructed were fairly stable, while in the latter case, it was unstable, hence various measures extending for a long 25 years necessitated. Hence, the river protection and flood control techniques are essentially site specific.

However, the common techniques to follow for mitigation of the river induced disasters require appropriate mathematical analysis, few of which have been included herein.

The probability of flood occurrence is given by [17]:

$$
P=\frac{(t / T)^{r}}{r !} \exp (-t / T)
$$

where, $r$ is the number of occurrences, $t$ the time period of interest and $T$ is the return period.

The soil erosion may be estimated by RUSLE method, given as [18]:

$$
A=R \cdot K \cdot L_{S} \cdot S \cdot C \cdot P
$$

where, $A$ is the mean annual soil loss per unit area, $R$ is the rainfall-runoff erosivity factor, $K$ is the soil erodibility factor, $L_{S}$ is the slope length factor, $S$ is the slope steepness factor, $C$ is the cropping management factor and $P$ is the support practice factor.

The hydrological risk analysis is an important parameter of analysis. Theoretically, risk is defined as the probability of failure when the external load in an engineering system exceeds the internal resistance. In flood control system, the relevant risk probability has been defined as [19]:

$$
P_{R}=P\left(H(t)>H_{S}\right)
$$

where, $P_{R}$ is the flood control risk probability, $H(t)$ is the HFL water level and $H_{S}$ is the design water level.

In order to design appropriate remedial measures, the standard design procedure should be followed based on the applicable design codes. The primary aim of such design is to provide adequate safety factor as well as 
serviceability requirements, apart from other important factors including construction feasibility, environmental sustainability, etc. [20].

Every field-based investigation emerges significant scope of future study [21]. The scope for future study in the selected sites follows a brief summary of the master-plan strategy, which appears to address the various flood issues and strategies under selected disciplines such as hydrology, geology, flooding, erosion, and flood proofing. Simultaneously, rigorous study of the effectiveness of the remedial measures undertaken including embankments, drainage, navigation, irrigation and storage dams would be of immense benefit to researchers and practicing engineers.

\section{Conclusions}

Geomechanical and hydrogeological hazards related to river hydraulics are rather common, but often quite detrimental, introducing serious disastrous consequences unless appropriate mitigation techniques are not adopted. In this paper, two selected case studies in India have been described, one in northern part and the other in the north-eastern part of the country. The important observations made are briefly summarized here.

The first study is the alluvial river basin of the Kosi river, which was observed to migrate significantly towards the west, with a peak migration rate attaining to as high as $2.5744 \mathrm{~km} /$ year. Such migration produced significant erosion and siltation, introducing severe environmental and civil hazards. Construction of appropriate barrage and associated hydraulic structures reduced such risks.

So far as the second study area is concerned, it is the Dibrugarh town and adjoining river basins of Brahmaputra. The primary hazard observed was frequent flood, which was associated with significant land erosion and also migration of river channel. The remedial measures undertaken were construction of spurs and associated hydraulic structures, adopting trial and error methods. Those measures were discretized into several phases.

While the induced hazards from river hydraulics and the required protective works are site specific, few common design techniques and application of proper mathematical correlations for flood probability and risk and erosion susceptibility would provide better solutions.

The entire investigation opens the scope of future research and development.

\section{Acknowledgements}

The authors thankfully acknowledge research data collected from various departments of Government of India and Assam, for this study. Assistances were also received from late Prof. Bharat Singh, former Vice Chancellor, University of Roorkee, India.

\section{References:}

[1] Grant, G. E., O’Connor, J. E. and Wolman, M. G., A river runs through it: conceptual models in fluvial geomorphology, Treatise on Geomorphology, vol. 9, pp. 6-21, 2013.

[2] Julien, P. Y., River Mechanics, Cambridge University Press, $2^{\text {nd }}$ Edition, 2018.

[3] Yang, C. T., On river meanders, Journal of Hydrology, vol.13, pp. 231-253, 1971.

[4] Herb Wiebe (2006). River Flooding and Erosion in Northeast India. Technical Report, Northwest Hydraulics Consultants, Alberta, Canada.

[5] Chakraborty, T., Kar, R., Ghosh, P., Basu, S., Kosi megafan: historical records, geomorphology and the recent avulsion of the Kosi River, Quaternary International, vol. 227, no. 2, pp. 143-160, 2010.

[6] Shrivastava, R.J. and Heinen, J.T., Migration and home gardens in the Brahmaputra valley, Assam, India". Journal of Ecological Anthropology, vol. 9, pp. 20-34, 2005.

[7] Chakraborty, T., Kar, R., Ghosh, P. and Basu, S., Kosi megafan: Historical records, geomorphology and the recent avulsion of the Kosi River, Quaternary International, vol. 227, no. 2, pp. 143-160.

[8] Armani, A., Principles of River Hydraulics, Springer link, 1999.

[9] Sinha, R., Gupta, A., Mishra, K., Tripathi, S., Nepal, S., Wahid, S. M. and Swarnkara, S., Basin-scale hydrology and sediment dynamics of the Kosi river in the Himalayan foreland, Journal of Hydrology, vol. 570, pp. 156-166.

[10] Devkota, L., Giri, S., Crosato, A. and Baral, B. R., Impact of the Koshi barrage and embankments on river morphology and dynamics, Proceedings, $7^{\text {th }}$ International Conference on Water Resources and Renewable Energy Development in Asia, Danang, Vietnam, 2013.

[11] Basack, S., Goswami, G., Deka, P., Borah, P. P. and Mastorakis, N., Analysis and control of flow parameters through sluice gate in dam, International Journal of Mechanics, vol. 14, pp. 22-27, 2020, DOI: 10.46300/9104.2020.14.3

[12] Uttarakhand River Rejuvenation Committee, Action Plan for Rejuvenation of River Kosi, District. US Nagar, Uttarakhand, Priority IV, 2019.

[13] Gole, C.V. and Chitale, S.V., Inland delta building activity of Kosi river, Journal of the Hydraulics Division, Proceedings of the American Society of Civil Engineers, vol. 92, no. HY2, pp 111-126, 1966. https://doi.org/10.1061/JYCEAJ.0001406

[14] Gilfelloni, G. B., Sarma, J. N. and Gohain, K., Channel and bed morphology of a part of the Brahmaputra river in Assam, Journal of Geological Society of India, vol. 62, pp. 227-235, 2003.

[15] Roy, N. and Pandey, W. B., Socio-economic appraisal of flood hazard among the riparian communities: case study of Brahmaputra valley in Assam; India, Proceedings, $19^{\text {th }}$ EGU General Assembly, Vienna, Austria, 2017, p.17653. 
[16] Brahmaputra Board, Annual Report 2018-2019, Basistha, Guwahati, p. 148, 2019.

[17] Samantaray, S. and Sahoo, A., Estimation of flood frequency using statistical method: Mahanadi river basin, India, $\mathrm{H}_{2}$ Open Journal, vol. 3, issue 1, pp. 189-207, 2020.

[18] K. G. Renard, G. R. Foster, D. K. Weesies, and D. C. Yoder, Predicting Soil Loss by Water: A Guide to Conservation Planning with the Revised Soil Loss Equation (RSULE), no. 2, U.S. Department of Agriculture, Washington DC, USA, 1997.

[19] Di, L., Zhou, J., Chen, L., Huang, K., Wang, Q. and Zha, G., Flood risk analysis based on a stochastic differential equation method, Journal of Flood Risk Management, vol. 12, Suppl. 1, pp. 1-10.

[20] Flood Management Organization, Handbook for Flood Protection, Anti Erosion \& River Training Works, Central Water Commission, Government of India, 2012.

[21] Basack, S., Goswami, G. and Nimbalkar, S., Analytical and numerical solutions to selected research problems in geomechanics and geohydraulics, WSEAS Transactions on Applied and Theoretical Mechanics, vol. 16, pp. 222231 , 2021 , http://dx.doi.org/10.37394/232011.2021.16.25

\section{Conflict of Interest Statement}

The authors declare that there is no conflict of interest in this paper. No financial support was received to carry out this study.

\section{Authors' Contributions}

Joydeep Dutta has carried out field studies, data collection and analysis; Sudip Basack is responsible for overall supervision, writing and compilation; Ghritartha Goswami and Bini Kiron have done the drafting and revision.

\section{Creatve Commons Attribution License 4.0} (Attribution 4.0 International, CC BY 4.0)

This article is published under the terms of the Creative Commons Attribution License 4.0

https://creativecommons.org/licenses/by/4.0/deed.en_US 